\title{
The Effect of Alkaline Material Particle Size on Adjustment Ability of Buffer Capacity
}

\author{
Girts BUMANIS ${ }^{1 *}$, Kristine RUGELE ${ }^{2,3}$, Diana BAJARE ${ }^{1}$
}

${ }^{1}$ Department of Building Materials and Products, Riga Technical University, Kalku iela 1, LV-1658, Riga, Latvia

${ }^{2}$ Department of Water Engineering and Technology, Riga Technical University, Azenes 16, LV-1048, Riga, Latvia

${ }^{3}$ Institute of General Chemical Engineering, Riga Technical University, Azenes 14, LV-1048, Riga, Latvia

crossref http://dx.doi.org/10.5755/j01.ms.21.3.7325

\section{Received 13 June 2014; accepted 26 December 2014}

\begin{abstract}
The $\mathrm{pH}$ control in biotechnological processes like anaerobic digestion is one of the key factors to ensure high efficiency in the biogas production process. The decrease of $\mathrm{pH}$ level in the digestion process occurs due to the rapid acid formation during metabolic processes of bacteria, which leads to the inhibition of the methane producing bacteria; therefore further digestion process is limited. The efficiency of anaerobic digestion reactor decreases dramatically if the $\mathrm{pH}$ level falls under $\mathrm{pH}$ 6.6. This problem is common for single-stage continuous digesters with a high organic solid content; therefore the active $\mathrm{pH}$ controlling method is commonly used. By creating inorganic alkaline material, the passive $\mathrm{pH}$ controlling system could be created. Soluble alkalis are enclosed in the matrix of material during the activation process thus providing slow leaching of free alkalis from the material structure in water medium and ensuring $\mathrm{pH}$ increase. In this research a porous alkaline composite material was developed as a $\mathrm{pH}$ controlling agent for the biogas production. Two mixture compositions with a different Si/Al and Si/Na ratio were created and tested. The effect of particle size of the material was investigated in order to provide different leaching rates for the described material. Granular material with particle fractions $1-2 \mathrm{~mm}, 2-4 \mathrm{~mm}$ and $4-8 \mathrm{~mm}$ and a cubical specimen with dimensions $20 \times 20 \times 20 \mathrm{~mm}$ were tested. The $\mathrm{pH}$ level of water medium increased up to $\mathrm{pH} 11.6$ during the first day and final $\mathrm{pH}$ value decreased to 7.8 after 20-day leaching. Alkali leaching can be increased by $19-32 \%$ with changing the mixture composition by adding glass powder to the alkaline material. The particle size factor had negligible effect on leaching rate of alkaline material due to the high porosity of material. Research results show that this composite material has a potential to be applied in $\mathrm{pH}$ control for biotechnological purposes.

Keywords: alkaline material, particle size effect, leaching, buffer capacity.
\end{abstract}

\section{INTRODUCTION}

Alkaline materials (AM) could be obtained from $\mathrm{Al}_{2} \mathrm{O}_{3}$ and $\mathrm{SiO}_{2}$ rich materials by using alkali activation technology. The reaction product or gel after activation process has a network structure similar to the organic thermoset polymers, and thus the binders are sometimes called "inorganic polymers" or "geopolymers" [1]. $\mathrm{Na}^{+}, \mathrm{K}^{+}$ ions create a strong base environment for the dissolution of glass phases from activated materials in accordance with the latest researches. $\mathrm{Na}^{+}, \mathrm{K}^{+}$ions are weakly bound in the nanostructure of the $(\mathrm{N}, \mathrm{K})-\mathrm{A}-\mathrm{S}-\mathrm{H}$ gel and therefore are almost completely leachable. This cause the AM to be prone to efflorescence with excessive remnants of alkalis in the system. (Na, K)OH easily diffuses to the surface, where it reacts with atmospheric $\mathrm{CO}_{2}$, while forming visible salts such as $\mathrm{Na}_{2} \mathrm{CO}_{3} \cdot \mathrm{nH}_{2} \mathrm{O}, \mathrm{NaHCO}_{3}, \mathrm{~K}_{2} \mathrm{CO}_{3}$, $\mathrm{KHCO}_{3}$ [2]. This could be a negative property for the material used in the construction industry; however, in the biotechnological processes continuous alkali leaching is an advantage in order to control $\mathrm{pH}$ levels. The leaching rate of $\mathrm{Na}^{+}$and $\mathrm{OH}^{-}$from the AAM activated with $\mathrm{NaOH}$ or $\mathrm{NaOH}$ with sodium silicate solution is high for the first few weeks, decreasing over time [3]. This is expressed with buffer capacity. The AM buffer capacity could be

\footnotetext{
${ }^{*}$ Corresponding author. Tel.: +371-26062011; fax: +371-67089248. E-mail address: girts.bumanis@rtu.lv (G. Bumanis)
}

described with free alkalis available for diffusion from the material structure. If $\mathrm{Na}^{+}$based activation solution is used for binder creation then $\mathrm{Na}^{+}$salts will be available for leaching. The activator type and concentration is one of the key factors affecting material properties and alkali diffusion rate [4], [5]. Time factor should be taken into account for material leaching properties due to the carbonization with the atmospheric $\mathrm{CO}_{2}$ because variable salts have different solubility rate in water. The mechanism and effects of the carbonization in alkali silicate-activated slags with different silicate modulus and metakaolin have been researched by Bernal [6].

By creating highly porous AM structure it could be possible to enclose alkalis inside the material structure, therefore providing alkalis available for leaching in longer period of time. The porous structure ensures a high surface area where $\mathrm{Na}^{+}$ions could diffuse. Gradual alkali release is an advantage for using material in biotechnologies [7]. The porous material structure can be obtained by mixing gasreleasing agents like aluminium paste [8]. However, waste materials, like non-metallic residues from aluminium scrap recycling industry, can be used [9].

A positive factor is the fact that alkalis could be leached out of the material structure without compromising mechanical properties; therefore this renders $\mathrm{Na}^{+}$as an unnecessary load-bearing element in the nanostructure of the $\mathrm{N}-\mathrm{A}-\mathrm{S}-\mathrm{H}$ gel and demonstrates $\mathrm{A}-\mathrm{S}-\mathrm{H}$ to be a loadbearing structure [2]. This provides an effective processing 
of AM in the biotechnologies. The AM could be described as filtering buffer capacity material which could be replaced by another cartridge filled with granular AM after complete diffusion of alkalis.

Granular AM with an increased amount of $\mathrm{SiO}_{2}$ has more expressive glassy phase, which is detected by XRD patterns with different $\mathrm{SiO}_{2}$ content; the broad peak, which was shifted to $28^{\circ} 2 \theta$ after alkali activation of metakaolin, has higher intensity with increase of $\mathrm{SiO}_{2}$ content which indicates amorphous material structure [10]. However high water absorption could still be obtained for such material, which is similar to foam glass granules also created from waste glass. The water absorption of such material could be up to $50 \%$ [11]. This could be a key factor of effective alkali diffusion from material structure due to high water absorption and filtration water available for leaching.

In the present research AM leaching properties were detected by the effect of grain size of granular porous AM and two different AM mixture compositions were tested.

\section{EXPERIMENTAL DETAILS}

The AM was created by using alkali activating technology with waste metakaolin (WMK) coming from UAB Stikloporas (Lithuania) production plant of foam glass granules, aluminium scrap recycling waste (ASRW) coming from the aluminium scrap recycling factory (Dilers Ltd., Latvia) and sodium silicate glass fibre waste (SFG) coming from JSC Valmiera Glass Fibre (Latvia). During industrial foam glass granule production kaolin has been used as releasing agent therefore kaolin has been calcined at $850{ }^{\circ} \mathrm{C}$ for about $40-50$ minutes and obtained WMK with fraction $<0.25 \mathrm{~mm}$ is a residue which must be disposed. The origin and chemical and mineralogical composition as well as other properties of ASRW are described in detail in the previously published papers [9]. The waste materials ASRW and SFG were ground for 30 minutes by using planetary ball mill Retsch PM 400 to obtain homogenous powder. The chemical composition of raw materials is given in Table 1 .

Table 1. Raw material mixture composition

\begin{tabular}{|c|c|c|c|}
\hline \multirow{2}{*}{ Compound } & \multicolumn{3}{|c|}{ Amount, wt.\% } \\
\cline { 2 - 4 } & WMK & SFG & ASRW \\
\hline $\mathrm{Al}_{2} \mathrm{O}_{3}$ & 40.2 & 2.8 & 63.2 \\
\hline $\mathrm{SiO}_{2}$ & 51.5 & 76.0 & 7.9 \\
\hline $\mathrm{CaO}$ & 2.0 & - & 2.6 \\
\hline $\mathrm{SO}_{3}$ & - & - & 0.4 \\
\hline $\mathrm{TiO}_{2}$ & 2.3 & - & 0.5 \\
\hline $\mathrm{Na}_{2} \mathrm{O}$ & 0.1 & 21.0 & 3.8 \\
\hline $\mathrm{K}_{2} \mathrm{O}$ & 0.5 & - & 3.8 \\
\hline $\mathrm{MgO}_{2}$ & 0.1 & - & 4.4 \\
\hline $\mathrm{Fe}_{2} \mathrm{O}_{3}$ & 1.2 & 0.1 & 4.5 \\
\hline $\mathrm{LOI}, 1000{ }^{\circ} \mathrm{C}$ & 2.0 & - & 6.2 \\
\hline $\mathrm{Total}$ & 99.9 & 99.9 & 97.4 \\
\hline
\end{tabular}

Alkali activating solution (AAS) was used for creating AM. AAS were prepared by using commercially available "Vincents Polyline" Ltd. (Latvia) sodium silicate solution characterized by the silica modulus Ms 3.22. The modification of sodium silicate solution with an addition of sodium hydroxide was done. Commercially available Tianye Chemicals Ltd. (China) sodium hydroxide flakes with $99 \%$ purity were used. AAS with silica modulus Ms 1.67 was prepared.

Two AM mixture compositions with different proportion of the solid raw materials were created. First composition (SG-0) consisted of ASRW, WMK and SFG with the mass ratio 1:1:0. The other composition (SG-1) contained SFG in equal proportion with ASRW and WMK $-1: 1: 1$. AAS to total solid raw materials ratio was 0.60 . The solid raw materials with proper mass ratio were mixed together and AAS were added. The following compound ratios were calculated: for GF-0 $\mathrm{SiO}_{2} / \mathrm{Al}_{2} \mathrm{O}_{3}$ was $0.9, \mathrm{SiO}_{2} / \mathrm{Na}_{2} \mathrm{O}$ was 3.5 and $\mathrm{Na}_{2} \mathrm{O} / \mathrm{Al}_{2} \mathrm{O}$ was 0.2 . The SFG incorporation in AM mixture composition changed material chemical composition for GF-1 to $\mathrm{SiO}_{2} / \mathrm{Al}_{2} \mathrm{O}_{3}$ 1.7, $\mathrm{SiO}_{2} / \mathrm{Na}_{2} \mathrm{O} 3.3$ and $\mathrm{Na}_{2} \mathrm{O} / \mathrm{Al}_{2} \mathrm{O} 0.5$ respectively (Table 2).

Since SFG is rich with $\mathrm{SiO}_{2}$ and $\mathrm{Na}_{2} \mathrm{O}$ (Table 1), the amount of mentioned compounds increases in the mixture composition; therefore higher $\mathrm{Na}_{2} \mathrm{O}$ content was expected to be available for leaching. According to the literature, an increased amount of $\mathrm{SiO}_{2}$ in the low-calcium systems promotes diffusion of the alkalis and thus initiates higher leaching amount of alkalis from material structure [12]. With the SFG presence in mixture composition, relative ASRW ratio decreases. As ASRW is a pore structure forming substance, the decrease of its relative amount could affect properties of the material structure like porosity and density.

Table 2. AM mixture composition

\begin{tabular}{|c|c|c|}
\hline \multirow{2}{*}{ Materials } & \multicolumn{2}{|c|}{ Mass ratio } \\
\cline { 2 - 3 } & GF-0 & GF-1 \\
\hline ASRW & 1.0 & 1.0 \\
\hline WMK & 1.0 & 1.0 \\
\hline SFG & - & 1.0 \\
\hline AAS & 0.6 & 0.6 \\
\hline Compounds & \multicolumn{2}{|c|}{ Molar ratio } \\
\hline $\mathrm{SiO}_{2} / \mathrm{Al}_{2} \mathrm{O}_{3}$ & 0.9 & 1.7 \\
\hline $\mathrm{SiO}_{2} / \mathrm{Na}_{2} \mathrm{O}$ & 3.5 & 3.3 \\
\hline $\mathrm{Na}_{2} \mathrm{O} / \mathrm{Al}_{2} \mathrm{O}_{3}$ & 0.2 & 0.5 \\
\hline
\end{tabular}

After mixing, the pastes were immediately poured into sealed prismatic moulds measuring $40 \times 40 \times 160 \mathrm{~mm}$. The amount of paste poured into the mould was calculated according to the expansion of each mixture avoiding limited expansion of paste. Moulds were covered with plastic film and samples were cured at $80^{\circ} \mathrm{C}$ for $24 \mathrm{~h}$.

After demoulding fractioned material of $\mathrm{AM}$ and cubical samples were prepared from both mixtures (GF-0 and GF-1). Granule fractions with particle sizes $<1 \mathrm{~mm}$; 1-2 mm, 2-4 mm and 4-8 $\mathrm{mm}$ were prepared by crushing hardened AM and cubical specimen with dimensions $20 \times 20 \times 20 \mathrm{~mm}$ was cut out of material structure.

The following physical properties of prepared porous AM samples were tested in accordance with EN 1097-6 and EN 1097-7: density, granule bulk density, material density, and water absorption, open and total porosity.

Buffer capacity was tested for 3 days old AAM by immersing the cubical specimen and granulate (weight $3.0 \pm 0.2 \mathrm{~g}$ ) in the deionized water and measuring the alkalinity kinetics within 20 days. Samples were moved to the new batch with deionized water $(100 \mathrm{ml})$ every $24 \mathrm{~h}$. 
The $\mathrm{pH}$ level of water solution was determined and alkalinity in $\mathrm{CaCO}_{3}$ equivalent as mg per litre $\mathrm{H}_{2} \mathrm{O}$ per $1 \mathrm{~g}$ of AAM $\left(\mathrm{CaCO}_{3}\right.$ eq. $\left.\mathrm{mg} / \mathrm{l} / \mathrm{g}\right)$ was calculated [13]. Samples were titrated with hydrochloric acid $0.01 \mathrm{M}$ to $\mathrm{pH} 4.5$ for determination of total alkalinity. Alkalinity in deionized water for all samples was measured every day.

Scanning electron microscope (SEM) (Tescan Mira/LMU) was used for microstructural characterization and BET method (QuadraSorb) was used to determine surface area of the AM before and after leaching test.

\section{RESULTS}

Physical properties of prepared AM are given in Table 3. Highly porous AM with total porosity from 83 to $84 \%$ was obtained. Density of hardened AM was $400 \mathrm{~kg} / \mathrm{m}^{3}$ for GF-0 and $468 \mathrm{~kg} / \mathrm{m}^{3}$ for GF-1. Material density was about the same, from 2.45 to $2.47 \mathrm{~g} / \mathrm{cm}^{3}$. The open porosity for GF-0 was $27 \%$ and for GF-1 - $24 \%$ respectively. Water absorption was higher for GF-0 - 66 \%, for GF-1 - $53 \%$.

The bulk density of AM having various particle sizes increases by the reduction of grain size (Table 3). Higher bulk density was observed for GF-1 compared to GF-0. Bulk density increases from 284 to $642 \mathrm{~kg} / \mathrm{m}^{3}$ for GF-0 and 300 to $713 \mathrm{~kg} / \mathrm{m}^{3}$ for GF-1. Particle size change from $1-2 \mathrm{~mm}$ to $4-8 \mathrm{~mm}$ increases bulk density from 284 to
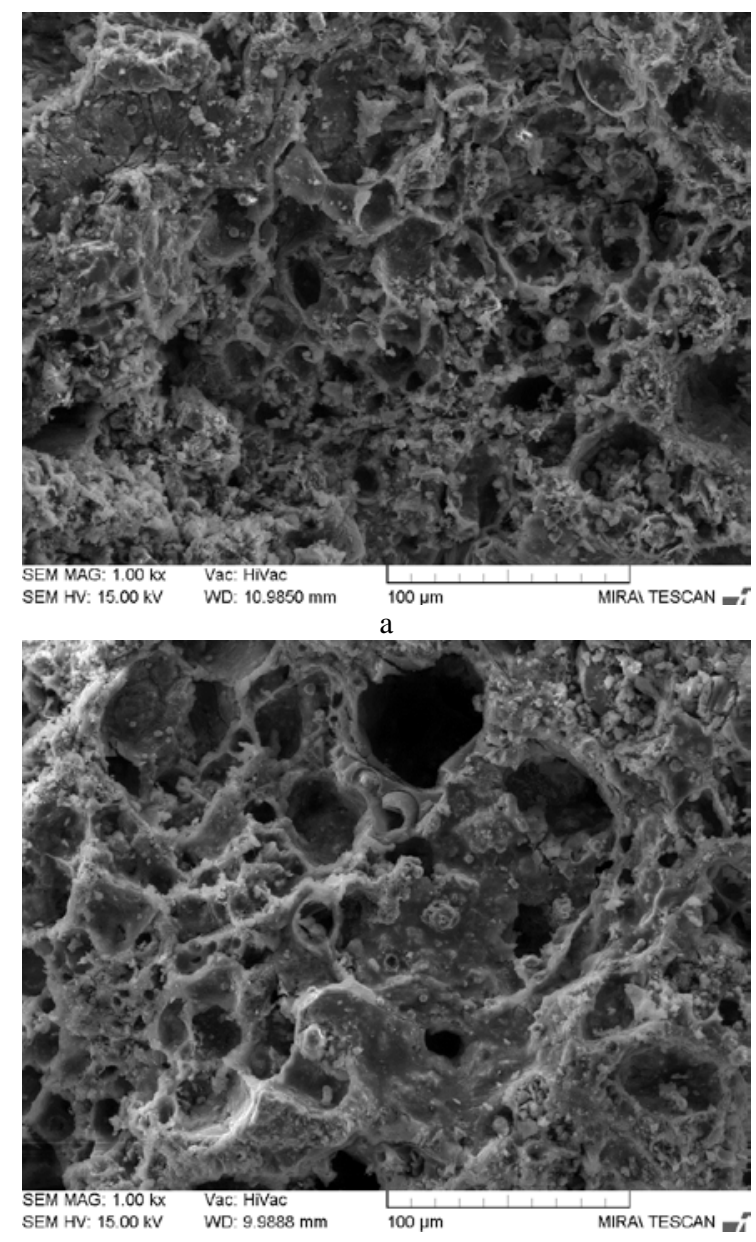

c
$389 \mathrm{~kg} / \mathrm{m}^{3}$ for GF-0 and 300 to $420 \mathrm{~kg} / \mathrm{m}^{3}$ for GF-1.

Table 3. Physical properties of AM and prepared AM grains

\begin{tabular}{|c|c|c|}
\hline \multirow{2}{*}{ Physical properties } & \multicolumn{2}{|c|}{ Mixture composition } \\
\cline { 2 - 3 } & GF-0 & GF-1 \\
\hline Density, kg/m ${ }^{3}$ & $400 \pm 12$ & $468 \pm 15$ \\
\hline Material density, g/cm ${ }^{3}$ & $2.45 \pm 0.03$ & $2.47 \pm 0.02$ \\
\hline Total porosity, \% & $84 \pm 1$ & $83 \pm 1$ \\
\hline Open porosity, \% & $27 \pm 2$ & $24 \pm 1$ \\
\hline Water absorption, wt.\% & $66 \pm 3$ & $53 \pm 1$ \\
\hline $\begin{array}{c}\text { BET surface area before } \\
\text { leaching test, } \mathrm{m}^{2} / \mathrm{g}\end{array}$ & $5.1 \pm 0.5$ & $4.8 \pm 0.5$ \\
\hline $\begin{array}{c}\text { BET surface area after } \\
\text { leaching test, } \mathrm{m}^{2} / \mathrm{g}\end{array}$ & $21.0 \pm 1.2$ & $15.5 \pm 0.8$ \\
\hline Fraction of AM & Bulk Density, $\mathrm{kg} / \mathrm{m}^{3}$ \\
\hline$<1 \mathrm{~mm}$ & $642 \pm 5$ & $713 \pm 10$ \\
\hline $1-2 \mathrm{~mm}$ & $389 \pm 5$ & $420 \pm 4$ \\
\hline $2-4 \mathrm{~mm}$ & $313 \pm 4$ & $347 \pm 3$ \\
\hline $4-8 \mathrm{~mm}$ & $284 \pm 3$ & $300 \pm 3$ \\
\hline
\end{tabular}

High density increase was observed for material with particle fraction $<1 \mathrm{~mm}$. The fine grain fraction $<1 \mathrm{~mm}$ was not included in further research due to its powder-like consistency which is not suitable for biotechnological purposes.

The microstructure of AM for both mixture compositions is given in Fig. 1. Fig. 1 a represents the microstructure of mixture GF-0.
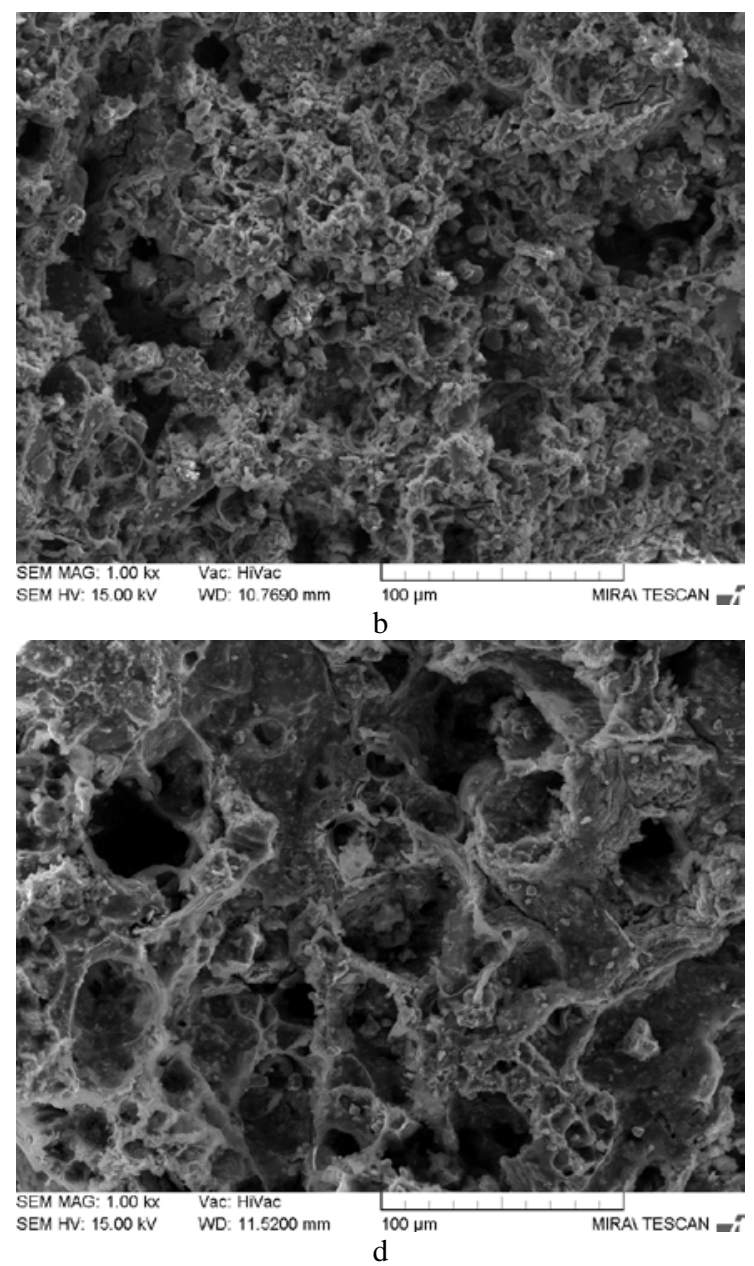

Fig. 1. Microstructure of AM before and after leaching tests: a-for GF-0; b-for GF-1 before leaching test; c-for GF-0; d-GF-1 after leaching test 
Highly porous structure of AM could be seen and various macro and micro pores were detected. For mixture GF-1 (Fig. 1 b) microstructure was similar to GF-0 and noticeable difference in microstructure was not detected. In the material pores free crystalline substances was present however after leaching test no crystals were detected (Fig. $1 \mathrm{c}$ and d). therefore it was assumed that these substances mainly affect the leaching and buffer capacity of AM which corresponds to the information in literature [2]. The BET surface area of AM before leaching test was $5.1 \mathrm{~m}^{2} / \mathrm{g}$ for GF-0 and $4.8 \mathrm{~m}^{2} / \mathrm{g}$ for GF-1. High surface area ensures high porosity and variable size of pores. After leaching test surface area of AM increased significantly. For GF-0 BET surface areas increased to $21.0 \mathrm{~m}^{2} / \mathrm{g}$ and for GF-1 - to $15.5 \mathrm{~m}^{2} / \mathrm{g}$ (Table 3 ).

The $\mathrm{pH}$ measurements during leaching tests were performed. Results are given in Fig. 2 and Fig. 3. For samples GF-0 particle size factor had negligible effect on $\mathrm{pH}$ level changes. The initial $\mathrm{pH}$ level for all samples was from $\mathrm{pH} 11.4-11.6$. The $\mathrm{pH}$ level decreased constantly during leaching test and on the day $20^{\text {th }}$ it reached $\mathrm{pH} 6.7$ for GF-0 with fraction $1-2 \mathrm{~mm}$ and slightly higher $\mathrm{pH} 7.5$ was with fraction 4-8 mm. For cubical specimen final $\mathrm{pH}$ was 6.8. The particle size impact on the $\mathrm{pH}$ level was more visible for AM with mixture composition GF-1. The initial $\mathrm{pH}$ level was from $\mathrm{pH} 11.4$ to 11.6 which was the same as for GF-0. However, during leaching test reduced particle size has led to more rapid $\mathrm{pH}$ decrease comparing to large size particles. On the $20^{\text {th }}$ day of leaching test the AM with $1-2 \mathrm{~mm}$ particles had $\mathrm{pH}$ level of 6.8 while for fraction $2-4 \mathrm{~mm}$ it was 7.0 and for $4-8 \mathrm{~mm}-8.3$ respectively. The cubical specimen with the largest dimensions provided $\mathrm{pH} 7.5$ on the $20^{\text {th }}$ day and it was lower than for $4-8 \mathrm{~mm}$.

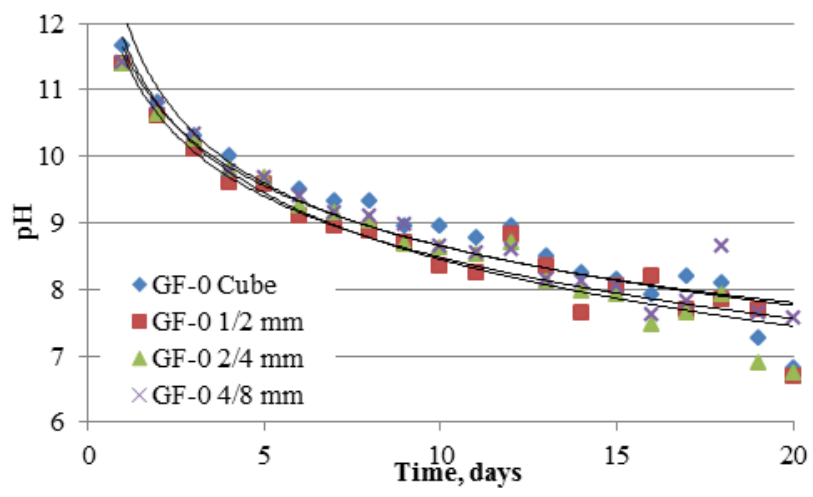

Fig. 2. pH level of AM GF-0 during leaching test

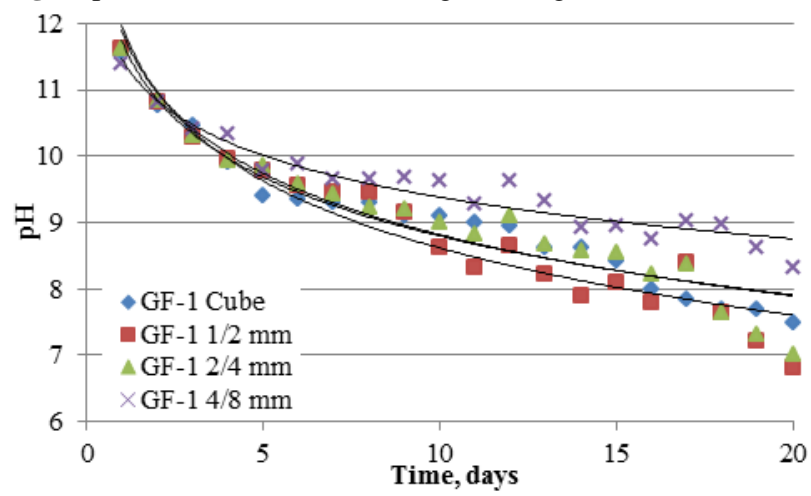

Fig. 3. pH level of AM GF-1 during leaching test
Leaching test results are given in Fig. 4 and Fig. 5. Total alkalinity curves expressed as $\mathrm{CaCO}_{3}$ equivalent $\mathrm{mg} / \mathrm{l} / \mathrm{g}$ show that AM mixture GF-0 made without SFG provides leaching from 771 to $858 \mathrm{CaCO}_{3}$ eq. mg/l/g (Fig. 4). The lowest leaching rate was for the finest particles $1-2 \mathrm{~mm}$ but the highest for cubical specimen and 4-8 mm particles - 858 and $843 \mathrm{CaCO}_{3}$ eq. mg/l/g.

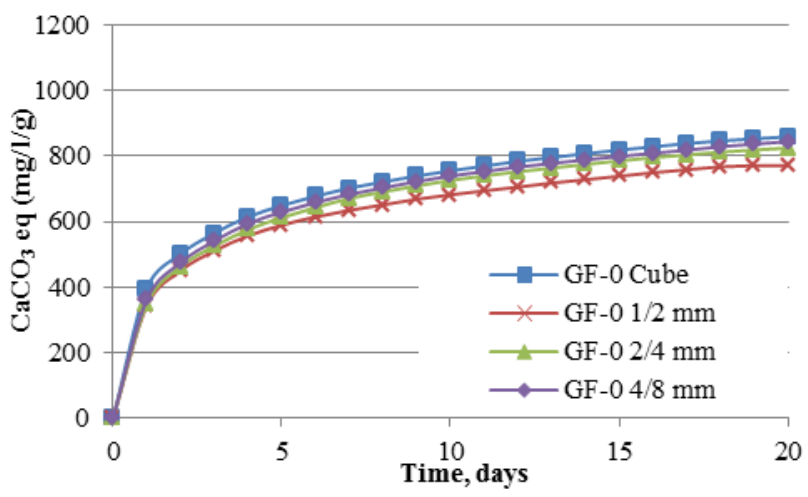

Fig. 4. Total alkalinity curves for GF-0 samples

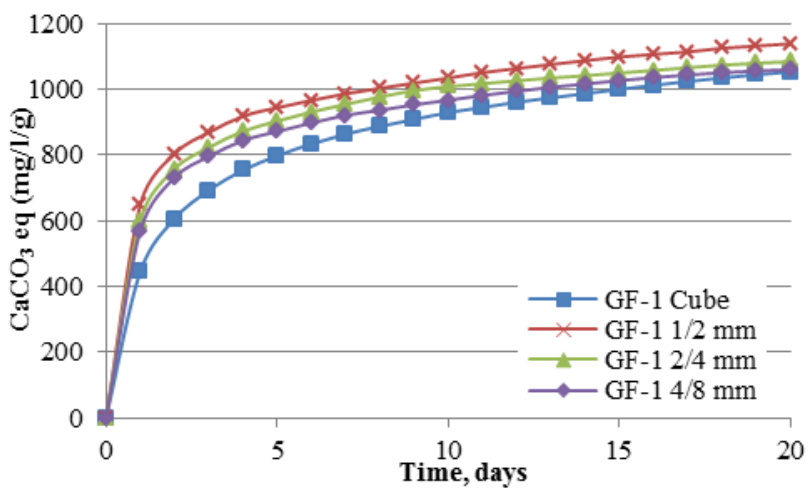

Fig. 5. Total alkalinity curves for GF-1 samples

Leaching rate for material GF-1 provides leaching from 1053 to $1139 \mathrm{CaCO}_{3}$ eq. mg/l/g. The lowest leaching rate was for cubical specimen and coarse fraction of granulate $(4-8 \mathrm{~mm})$ - from 1053 to $1060 \mathrm{CaCO}_{3}$ eq. $\mathrm{mg} / \mathrm{l} / \mathrm{g}$. Fine particles $(1-2 \mathrm{~mm}$ and $2-4 \mathrm{~mm}$ ) provide higher leaching rate - 1138 and $1084 \mathrm{CaCO}_{3}$ eq. mg/l/g respectively.

\section{Discussion}

The particle size factor has an important effect on the material bulk density. The decrease of particle size increases bulk density for both AM mixture compositions. The physical properties of AM were also affected by the AM composition with SFG in the mixture composition. By incorporation of SFG slightly denser AM was obtained and grain density increased from 6-11\%. The water absorption decreased by SFG incorporation by $20 \%$. The increase of glassy phase in AM structure reduced open porosity by $11 \%$. Therefore the leaching properties of AM could be affected by granule particle size due to different physical properties of the AM. The particle size factor could propose the increase of leaching of alkalis due to reduced particle size and more open structure available for leaching. The BET surface area increase indicates the solubility of inner structure elements of AM. During the 
leaching test, free alkalis leach from the structure of AM revealing a high surface area.

All AM particle fractions made from mixture composition GF-0 provided gradual and even $\mathrm{pH}$ level decrease during time that could be explained with high water absorption. AM particle size effect did not play an important role of enclosure of alkalis inside the structure due to high open porosity; therefore particle size did not prevent or retard alkali leaching. Different situation was for GF-1. Lower open porosity and water absorption did not allow complete leaching of free alkalis; therefore AM with larger particle size remained $\mathrm{pH}$ level higher during the test while the AM with small particles size of 1-2 mm was open for leaching and rapid $\mathrm{pH}$ decrease was observed.

The total alkalinity of AM made without SFG was significantly lower comparing to AM made with SFG. Total alkalinity was from 18.5 to 32.3 \% lower for GF-0 comparing to GF-1. The phenomena, that for the material with mixture composition without SFG (GF-0) leaching rate for finer particles (1-2 $\mathrm{mm}$ and $2-4 \mathrm{~mm}$ ) was lower comparing to coarse particles $(4-8 \mathrm{~mm}$ and cubical specimen) but for composition with SFG (GF-1) the tendencies were opposite, must be investigated further. This could be explained by different mixture composition and granule preparation technique. During crashing and screening of AM, some free alkali crystals may leave the structure of AM therefore larger granule size prevents alkali loss from material structure therefore ensuring higher leaching and buffer capacity properties. Also high water absorption and negligible bulk particle density difference could lead to similar leaching rate for fractioned AM. Lower amount of $\mathrm{SiO}_{2}$ and $\mathrm{Na}_{2} \mathrm{O}$ content for AM GF0 reduces amount of alkalis leached from structure of AM.

High amount of alkalis leached during the first day. For AM GF-0 42 to $46 \%$ of alkalis had leached after the first day. The size of AM particles insignificantly affected the early leaching rate. For cubical specimen it was $46 \%$ but for various particle fractions it was from 42 to $45 \%$. Particle size effect at first day of leaching was more variable for AM GF-1 ranging from 42 to $57 \%$. For coarse fraction lower amount of alkalis leached during the first day. Cubical specimen leached $42 \%$ but particle size decrease increased the amount of leached alkalis from 54 to $57 \%$.

\section{CONCLUSIONS}

The particle size effect on the leaching properties is affected by mixture composition used to create the AM. The AM with SFG in composition has high $\mathrm{SiO}_{2}$ and $\mathrm{Na}_{2} \mathrm{O}$ content and more variations in fractioned AM leaching properties comparing to AM without SFG was observed. Therefore for AM with increased amount of $\mathrm{SiO}_{2}$ particle size effect must be taken into account, while for reduced amount of $\mathrm{SiO}_{2}$ particle size does not play an important role. Both the physical properties of $A M$ and the fraction size determines leaching rate for the material. AM with high open porosity ensures rapid early alkali leaching. For the use in biotechnological purposes more even leaching rate should be obtained; therefore possible modifications of the material should be an object of further research to ensure stable leaching rate in prolonged period of time.

\section{Acknowledgments}

This work has been supported by ESF project „Involvement of Human Resources for Development of Integrated Renewable Energy Resources Energy Production System”, No. 2013/0014/1DP/ 1.1.1.2.0/13/APIA/VIAA/026.

\section{REFERENCES}

1. Juenger, M. C. G., $\quad$ Winnefeld, F., Provis, J. $\quad$ L., Ideker, J. H. Advances in Alternative Cementitious Binders Cement and Concrete Research 41 (12) 2011: pp. $1232-1243$.

http://dx.doi.org/10.1016/j.cemconres.2010.11.012

2. Škvara, F., Šmilauer, V. A Weak Alkali Bond in (N, K)A-S-H Gels: Evidence from Leaching and Modeling Ceramics-Silikaty 56 (4) 2012: pp. 374-382.

3. Aly, Z., Vance, E. R., $\quad$ Perera, D. S., Hanna, J. V., Griffith, C. S., Davis, J., Durce, D. Aqueous Leachability of Metakaolin-Based Geopolymers with Molar Ratios of $\mathrm{Si} / \mathrm{Al}=1.5-4 \quad$ Journal of Nuclear Materials $378(2)$ 2008: pp. $172-179$.

http://dx.doi.org/10.1016/j.jnucmat.2008.06.015

4. Bumanis G., Bajare, D., Locs, J. The Effect of Activator on the Properties of Low-Calcium Alkali-Activated Mortars Key Engineering Materials 604 2014: pp. 169-172. http://dx.doi.org/10.4028/www.scientific.net/KEM.604.169

5. Rugele, K., Bumanis, G., Bajare, D., Lakevics, V., and Rubulis, J. Alkaline Activated Material for $\mathrm{pH}$ Control in Biotechnologies Key Engineering Materials 604 2014: pp. 223-226.

6. Bernal, S. A., de Gutierrez, R. M., Provis, J. L., Rose, V. Effect of Silicate Modulus and Metakaolin Incorporation on the Carbonation of Alkali Silicate-activated Slags Cement and Concrete Research 40 (6) 2010: pp. 898-907.

7. Rugele K., Bumanis G., Erina L., Erdmane, D. Composite Material for Effective Cheese Whey Anaerobic Digestion Key Engineering Materials 604 2014: pp. 236-239.

8. Zhang, Z., Provis, J. L., Reid, A., Wang, H. Geopolymer Foam Concrete: An Emerging Material for Sustainable Construction Construction and Building Materials 56 2014: pp. $113-127$. http://dx.doi.org/10.1016/j.conbuildmat.2014.01.081

9. Bajare, D., Korjakins A., Kazjonovs, J., Rozenstrauha, I. Pore Structure of Lightweight Clay Aggregate Incorporate with Non-metallic Products Coming from Aluminium Scrap Recycling Industry Journal of the European Ceramic Society 32 2012: pp. 141-148.

10. Bumanis, G., Bajare, D., Locs, J., Korjakins, A. Alkalisilica Reactivity of Foam Glass Granules in Structure of Lightweight Concrete Construction and Building Materials 47 2013: pp. 274-281.

11. Bajare, D., Korjakins, A., Kazjonovs, J. Application of Aluminium Dross and Glass Waste for Production of Expanded Clay Aggregate Civil Engineering '11, 3rd International Scientific Conference, Proceedings 3 2011: pp. $27-31$.

12. Lloyd, R. R., Provis, J. L., Deventer, J. S. J. Microscopy and Microanalysis of Inorganic Polymer Cements. 1: Remnant Fly Ash Particles Journal of Material Science 44 (2) 2008: pp. 608-619.

13. Snoeyink, V L., Jenkins, D. Water Chemistry. New York: John Wiley \& Sons, 1980. 